12. Sviridovska, L. (2016). Civic education of future music teachers: Based on Ukrainian music classics. Current issues of culturology. № 16. P. 134-138, Rivne [in Ukrainian].

13. Stepanenko, M. (1989). Piano art of Ukraine in the period before Lysenko. Candidate's thesis: 17.00.02 "Musical art", Kyiv [in Russian].

14. Encyclopedia of Ukrainian music. (2006). Volume 1 [A-D], Ed. H. Skrypnyk. Kyiv: Publishing House of the Institute of Art History, Folklore and Ethnology of the National Academy of Sciences of Ukraine [in Ukrainian].

15. Furdui, Yu. V. (2018). The rhythmological aspects of the genre evolution of the piano bagatelle. Candidate's thesis: 17.00. 03 "Musical art", Odessa [in Ukrainian].

16. Shesterenko, I.V. (2008). Art of Vitaliy Kireiko in the course of the history of Ukrainian music. Kyiv: Kupriianova O.O. [in Ukrainian].

17. Shmurak, A. Alexey Shmurak's project "Insignificant music". URL: http://classicalforum.ru/index.php?topic $=8245.0$ [in Russian].

18. Yakubiak, Ya.V. (1997). Kolessa as a composer. Mykola Kolessa composer, conductor, teacher: a collection of articles, P. 21-29. Lviv [in Ukrainian].

УДК 784.5

DOI https://doi.org/10.31723/2524-0447-2020-30-2-10

Ірина Геннадї̈вна Шевчук

ORCID: 0000-0002-9334-8449

здобувач кафедри історії музики та музичної етнографіі

Одеської національної музичної академії імені А. В. Нежданової

filichita120@ukr.net

\title{
КАНТАТА К. СТЕЦЕНКА «ШЕВЧЕНКОВІ» У РІЧИЩІ ДУХОВНИХ НАСТАНОВ УКРАЇНСЬКОЇ КУЛЬТУРИ ПОЧАТКУ ХХ СТОЛІТТЯ
}

Мета роботи - виявлення поетико-інтонаційної унікальності хорової кантати K. Стеценка «Шевченкові» у контексті духовно-етичних шукань української культури початку ХХ століття та ї̈ славословної якості. Методологія дослідження спирається на інтонаційну концепцію музики в ракурсі інтонаційно-стилістичного аналізу, спадкоємного від Б. Асаф’єва та його послідовників, а також на міждисциплінарний

(C) Шевчук I. Г., 2020 
та історико-культурологічний підходи. Останні дозволяють виявити духовно-смислову та стильову специфіку української культури і музики вказаного періоду та виділити їх із загальноєвропейського культурного ареалу. Наукова новизна роботи полягає у збагаченні уявлень про поетику хорової творчості К. Стеценка, зокрема кантати «Шевченкові», що виступає одним із показових зразків української хорової традиції зазначеного періоду і водночас демонструє їі глибинний зв'язок із духовною генезою української культури. Висновки. Хорова кантата є одним із показових жканрів української музично-історичної традиції, поетика якого виступає своєрідною єднальною ланкою між літургічною та паралітургічною сферами творчості. Особливе акцентування славословної складової частини в кантаті зумовлене етимологією їі кореневої основи (“сапо" - «співати», «оспівувати», «прославляти»), грунтується на давніх традиціях української культури. Хорова кантата являє собою один із показових жканрових зразків утілення «алілуйної парадигматики європейської культури та музики» (А. Татарнікова), що тяжіє до уславлення значних постатей українського духовно-історичного буття, які єднають спільноту та репрезентують ї̈ національну ідею. Одне із провідних місць у иьому переліку належить Тарасу Шевченку, чий спадок узагальнює найбільш показові якості українського духовного світовідчуття, що набували особливої актуальності в період національного відродження межі ХІХ-ХХ століть. Поетика хорової кантати К. Стеценка «Шевченкові» апелює, з одного боку, до типологічних ознак славослівної кантати та їі музично-риторичної символіки (юбіляції, барокові протиставлення solo та tutti, звертання до поліфонічних форм викладення у фінальній частині твору як ознаки глоріозного жканру). 3 іншого боку, епіко-славільний тонус твору К. Стеценка, особливо його заключного розділу, виявляє співвіднесеність із композиційними настановами українських дум, зокрема з їхніми фінальними «славнями».

Ключові слова: кантата, славослів'я, украӥнська хорова кантата, українська культура початку ХХ століття, хорова творчість К. Стеценка, кантата «Шевченкові».

Shevchuk Iryna Henadiievna, Applicant at the Department of Music History and Ethnography of the Odessa National A. V. Nezhdanova Academy of Music

Kantata of K. Stetsenko "Shevchenkovi" in the flow of spiritual instructions of Ukrainian culture of the beginning of the $X X$ century

Research objective. The purpose of the work is to reveal the poetic and intonational uniqueness of K. Stetsenko's choral cantata "Shevchenko" in the context of spiritual and ethical pursuits of Ukrainian culture of the early twentieth century and its glorious quality. The methodology of the work is based on the intonation concept of music in the perspective of intonationstylistic analysis, inherited from B. Asafyev and his followers, as well as on interdisciplinary and historical-cultural approaches. The latter allow to identify the spiritual, semantic and stylistic specifics of Ukrainian culture and music of this period and to distinguish them from the European cultural area. 
The scientific novelty of the work lies in the enrichment of ideas about the poetics of choral work by K. Stetsenko, in particular the cantata "Shevchenko", which is one of the examples of Ukrainian choral tradition of this period and, at the same time, demonstrates its deep connection with the spiritual genesis of Ukrainian culture. Conclusions. Choral cantata is one of the demonstrative genres of the Ukrainian musical-historical tradition, the poetics of which acts as a kind of connecting link between the liturgical and paraliturgical spheres of creativity. The special emphasis of the eulogy component in the cantata, due to the etymology of its root base ("cano" - "sing", "sing", "glorify"), is based on the ancient traditions of Ukrainian culture. The choral cantata is one of the illustrative genre examples of the embodiment of the "alleluia paradigm of European culture and music" (A. Tatarnikova), which tends to glorify significant figures of Ukrainian spiritual and historical life that unite the community and represent its national idea. One of the leading places in this list belongs to Taras Shevchenko, whose legacy summarizes the most significant qualities of the Ukrainian spiritual worldview, which became especially relevant during the national revival of the turn of the XIX-XX centuries. The poetics of K. Stetsenko's choral cantata "Shevchenko" appeals, on the one hand, to the typological features of the glorious cantata and its musicalrhetorical symbolism (jubilee type of melody, baroque oppositions of solo and tutti, appeal to polyphonic forms of presentation in the final part of the work as signs of glorious genre). On the other hand, the epic-glorious tone of $K$. Stetsenko's work, especially its final section, reveals its correlation with the compositional guidelines of the Ukrainian Dumas, in particular with their final "glories".

Key words: cantata, eulogy, Ukrainian choral cantata, Ukrainian culture of beginning of XX century, choral work of K. Stetsenko, cantata "Shevchenko".

Шевчук Ирина Геннадиевна, соискатель кафедры истории музыки и музыкальной этнографии Одесской национальной музыкальной академии имени А. В. Нежждановой

Кантата К. Стеценко "Шевченко» в русле духовных установок украинской культуры начала ХХ столетия

Цель работы - выявление поэтико-интонацинной уникальности хоровой кантаты К. Стеценко «Шевченко» в контексте духовно-этических исканий украинской культуры начала ХХ века и ее славословного качества. Методология исследования опирается на интонационную концепцию музыки в ракурсе интонационно-стилистического анализа, унаследованного от Б. Асафьева и его последователей, а также на междисииплинарный и историко-культурологический подходы. Последние позволяют выявить духовно-смысловую и стилевую специфику украинской культуры и музыки указанного периода, выделить их из общеевропейского культурного ареала. Научная новизна работы состоит в обогащении представлений о поэтике хорового творчества K. Стеценко, в частности кантаты «Шевченко», выступающей одним из показательных образиов украинской хоровой традиции указанного периода и одновременно демонстрирующей ее глубинную связь с духов- 
ным генезисом украинской культуры. Выводы. Хоровая кантата - один из показательных жанров украинской музыкально-исторической традиции, поэтика которого выступает своеобразным связующим звеном между литургической и паралитургической сферами творчества. Акцентирование славословной составляющей в кантате, обусловленное этимологией ее корневой основы (“сапо” - «петь», «воспевать», «прославлять»), базируется на древних традициях украинской культуры. Хоровая кантата является одним из показательных образцов воплощения «аллилуйной парадигмы европейской культуры и музыки» (А. Татарникова), тяготеющих к прославлению значительных личностей украинского духовно-исторического бытия, объединяющих сообщество и репрезентирующих ее национальную идею. Одно из ведущих мест в этом перечне принадлежит Тарасу Шевченко, чье наследие обобщает наиболее показательные качества украинского духовного мироошущения, актуализировавшиеся в период национального возрождения на рубеже $X I X-X X$ веков. Поэтика хоровой кантаты К. Стеценко «Шевченко» апеллирует, с одной стороны, к типологии славословной кантаты и ее музыкально-риторической символике (юбиляции, барочные противопоставления solo и tutti, обращение $\kappa$ полифоническим формам изложения в финальной части произведения как признаку глориозного жканра). С другой стороны, эпико-славильный тонус произведения K. Стеценко, особенно его заключительного раздела, выявляет соотнесенность с композиционными установками украинских дум, в том числе с их финальными «славнями».

Ключевые слова: кантата, славословие, украинская хоровая кантата, украинская культура начала ХХ столетия, хоровое творчество К. Стеценко, кантата «Шевченко».

Актуальність теми дослідження. Ще в часи зародження античної філософії Платон зазначав, що «ім'я - це оприлюднення сутності» [цит. за: 2, с. 21]. На новому духовно-естетичному рівні ця ідея набула актуальності вже у XX ст. в культурологічних працях П. Флоренського й естетико-герменевтичних узагальненнях Г. Шпета, переконаних у тому, що у своїй етимологічній першорядності буття репрезентує себе частіше у формах іменної символіки, завдяки чому «етимологія починає відігравати роль наукового аргументу» [9, с. 15]. Сказане $\epsilon$ співвідносним і з поетикою жанру кантати та його типологічними ознаками, генеза яких сходить до етимології його кореневої основи та іï досить широкого смислового спектра, що охоплює не тільки власне «спів», але й «прославлення», «проголошення» [10]. Цей жанр набув особливої популярності в останні століття, відіграв роль певної ланки, що єднає літургійну та світську сфери музичної творчості та водночас 
репрезентує національну культуру різних регіонів Європи. Сказане стосується й українського музичного здобутку XIX початку XX ст., у межах якого саме жанр хорової славильної кантати посідає одне із суттєвих місць, зокрема й у творчості М. Лисенка, П. Сокальського, Д. Січинського, а також К. Стеценка. Її типологічні ознаки формувалися на перетині української фольклорної, богослужбово-співацької традиції та духовно-архетипових ідей-настанов, що єднали націю, серед іншого, і через оспівування значних постатей національної історії та культури, серед яких суттєве місце посідає Т. Шевченко. Затребуваність зразків української хорової кантати названих авторів, зокрема і твору К. Стеценка «Шевченкові», у сучасній виконавській практиці в паралелі з осмисленням національного хорового співу як утілення генетичного коду нації визначає актуальність теми представленої статті.

Мета дослідження - виявлення поетико-інтонаційної унікальності хорової кантати К. Стеценка «Шевченкові» у контексті духовно-етичних шукань української культури початку XX ст. та її славословної якості.

Наукова новизна. Аналіз досліджень і публікацій останніх десятиліть виявляє зростання інтересу до творчої спадщини й особистості К. Стеценка. Духовна складова частина його творів стала предметом цікавих наукових розвідок Л. Пархоменко [15], Н. Костюк, С. Лісецького, С. Федотова й інших, що спираються також на зібрання публікацій, листів, спогадів самого К. Стеценка [12]. Виділяємо також сучасні роботи М. Юрченка, О. Козаренка, Д. Гайдучик [3], 3. Гнатів, Н. Синкевич [17], І. Бермес та інших, що свідчать про глибинний зв'язок творчості К. Стеценка та його сучасників із духовним підгрунтям вітчизняної християнської хорової культури та іiі сакрального грунту. Водночас поза увагою залишається зв'язок творів композитора, зокрема кантати «Шевченкові», 3 релігійно-архетиповими настановами української культури та iіi славословної складової частини, а також духовно-естетичними шуканнями українського модерну початку XX ст.

Методологія роботи спирається на інтонаційну концепцію музики в ракурсі інтонаційно-стилістичного аналізу, спадкоємного від Б. Асаф'єва та його послідовників, а також на міждисциплінарний та історико-культурологічний підходи. Останні дозволяють виявити духовно-смислову та стильову специфіку української культури і музики вказаного періоду, 
виділити їх із загальноєвропейського культурного ареалу. Наукова новизна роботи полягає у збагаченні уявлень про поетику хорової творчості К. Стеценка, зокрема кантати «Шевченкові», що виступає одним із показових зразків української хорової традиції зазначеного періоду і водночас демонструє іiі глибинний зв'язок із духовною генезою української культури.

Виклад основного матеріалу. За всю свою більш ніж 300-річну історію існування кантата пройшла досить значний шлях розвитку, визначилась водночас у своїх базових жанрових показниках. Від самого початку за етимологією свого найменування даний жанр чітко співвідноситься саме зі сферою вокальної духовної творчості, складає певну опозицію інструменталізму.

Етимологія слова «кантата», похідного від “cant”, “canto" та його аналогів, що, у свою чергу, сходять до більш давніх мовних витоків, зокрема до “сапо", має досить широкий смисловий спектр - «співати», «кричати», «грати (на музичному інструменті)», «звучати», «оспівувати», «прославляти», «сповіщати», «пророкувати» тощо [10]. Аналогічного роду смислова багатогранність характеризує і феномен канта, що $є$ досить популярним в українській музично-історичній традиції минулого. Етимологічно похідний від лат. cantus («спів») і його численних термінів-аналогів («кантилена», «кантилляція», «кантор», “cantus planus", "chant”, «канцона», «кантата» тощо), «кант виявився генетично вкоріненим в європейській культурі, починаючи з раннього Середньовіччя, про свідчать західні енциклопедичні видання, а також дослідження зарубіжних візантиністів і медієвістів <...> Мова йде про «кант» як plain song, «простий спів різних християнських церков», який не ототожнюється 3 «хоралом»» [цит. за: 14, с. 283] і, додамо, є активно затребуваним як у літургічній, так і в позалітургічній практиці.

Диференціювання зразків кантати Нового часу на «духовний» та «світський» різновиди не виключає, однак, їхньої орієнтації в будь-якому разі на узагальнене втілення високої, сакральної духовно-релігійної або морально-етичної ідеї, суттєвої для національної культури, суспільного життя певного періоду, «розкриваючи іiі в ліричному чи лірико-епічному плані. Виконується кантата як вітальний гимнічний

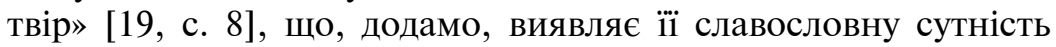
як основну якість. Становлення української хорової кантати відбувалося в річищі взаємовпливів багатьох типологій, серед 
яких більшість дослідників виділяють хоровий (партесний) концерт, панегіричний кант та інші різновиди цього жанру, а також творчість найбільш видатних постатей вітчизняного хорового мистецтва XVIII - початку XX ст.

Особливе акцентування славослівної складової частини в кантаті грунтується на давніх традиціях як української, так і слов'янської загалом культури, про що свідчать наукові розвідки А. Плотнікової [16], І. Дзюби [5, с. 618-637], Т. Агапкіної [1]. Ю. Ясиновський у результаті дослідження зв’язків між візантійською гімнографією й українською богослужбово-співацькою практикою виявляє суттєву роль у вітчизняній культурі, починаючи із часів Київської Русі, жанру «пісні-хвали», у якому «оспівувався героїзм князів в обороні рідної землі. Вони (пісні-хвали])тісно були пов'язані з билинною епікою, фольклорними жанрами, зокрема, колядками та веснянками, південнослов'янськими «славами» на честь патріярхів роду; пізніше українські думи генетично також були пов'язані з піснями-хвалами». Ю. Ясиновський досліджує цю образно-смислову «лінію» національної культури, що виявилася актуальною також і на початку XX ст., зокрема і в хоровій спадшині М. Лисенка та К. Стеценка (зокрема, у кантаті «Шевченкові»), також убачає «коріння» цієї славословної традиції і у візантійських акламаціях - «прославних співах придворних церемоній» [20, с. 42-43].

У світлі зазначеної славословної проблематики актуальними вважаємо ідею та матеріали монографії А. Татарнікової «Алілуйна парадигма європейської культури і музики (від готики до сучасності)» [18], предмет якої звернений до всебічного дослідження культури славослів'я в релігійній та позарелігійній мистецькій практиці соціуму. На основі залучення значного матеріалу не тільки музичного мистецтва Європи (зокрема, й українського), але й іiі літературного та художньо-образотворчого спадку, автор узагальнює найбільш типові семантичні показники та настанови позначеної «парадигми», генеза якої укорінена в ідеї похідності культури від культу. У межах даної концепції особливу увагу акцентовано на образах слави, хвали, подяки, шанування, радості, краси, екстатики, закарбованих у поетиці містерії, міраклю, гімну, псалма, оди, панегірика, дифірамба, Te Deum, Gloria, кантатно-ораторіальної сфери творчості, різноманітних форм доксології, славослів'я та їх художньо-виразного втілення. 
Культова генеза зазначених рис «алілуйної парадигми європейської культури», на думку дослідниці, «невіддільна також від ідеї вищого духовного Божественного Порядку (ordo) i показової для нього Ієрархії, похідних від сакральних першоджерел <..> Проєктування цієї ідеї в земному світі виявляється в сакральному піднесенні фігури монарха як гаранта Порядку, у виявленні духовних настанов існування національної державності та супутніх їй атрибутів. При інших формах державотворення (відсутність монархічно-імперської форми управління, наприклад, в українській історії) ідея Порядку виявляється зосередженою на ключових принципах духовно-релігійного буття нації, мислення етапів іії історії в біблійних категоріях, шануванні іiі святинь та архетипових настанов». Згідно з висновками А. Татарнікової, «об'єктами хвали виступають носії національної ідеї, а також видатні історичні постаті та митці, діяльність яких духовно єднає націю та обумовлює суттєву роль в цих процесах саме славословної тематики» [18, с. 285-286]. Відзначимо, що однією з таких постатей для українського світосприйняття, безсумнівно, є Тарас Шевченко, творчість та особистість якого надихали багатьох українських (і не тільки) митців XIX-XX ст., зокрема i К. Стеценка (див. нижче).

Славослівний аспект у поєднанні із традиціями національного хорового співу показовий, як зазначено раніше, і для української фольклорної традиції (колядки, щедрівки, думи із заключним «славнем»), і для сакрального живопису (іконографія «Христа у славі»), і для національного світовідчуття загалом. На думку Б. Стебельського, слава - це «не лише одна 3 духовних цінностей, а найвищий вияв морально-етичних цінностей, пошанованих українцями як «кодекс честі». Саме таке уявлення про честь і славу - і свою особисту, і свого народу - сповідував Кобзар. С. Смаль-Стоцький характеризує концептуальні засади творчості Т. Шевченка так: «Через правду до волі, а такі до слави, святої слави» [13, с. 59]. Відзначимо, що саме ці якості особистості Кобзаря та їх відображення в українській народній свідомості були втілені в поетичній основі (К. Малицька) та музиці кантати К. Стеценка «Шевченкові».

Повертаючись до огляду ролі славословної тематики в українському образі світу та культури, відзначимо іiі вирішальне значення і в образотворчому мистецтві, починаючи з ренесан- 
сної доби. У його найкращих творах, на думку авторів «Істоpiї українського мистецтва», «гармонія й пропорційність <...> виражаються в помірному рухові. I це не звичайний побутовий рух, а врочистий». Його продовження дослідники також бачать і в «панегіризмі» українського бароко: «На Заході він пишномовний, величальний, з перебільшенням чеснот владних персон; спокійніший у похвалах панегіризмів в Україні, де героями виступають талановиті люди, побожні християни, патріотичне козацтво» [6, с. 969, 970], що становили духовно-аристократичну еліту української спільноти.

В умовах цієї культури відбувалися також процеси формування жанрової сфери української хорової музики, зокрема й кантати. Її найкращі зразки, створені в період XVIII-XIX ст., репрезентовані у творчості Д. Бортнянського («Любителю художеств», «Страны российски, ободряйтесь», «На возвращение императора Александра I»), П. Сокальського («Бенкет Петра Великого»), М. Лисенка («Іван Гус», «Б'ють пороги», «Радуйся, ниво неполитая», «На вічну пам'ять Котляревському»), Д. Січинського («Дніпро реве»), Г. Топольницького («Хустина»), Й. Кишакевича («Дума», «Катерина») та інших. Як бачимо, значна кількість названих творів або створювалися в межах виконання обов'язків придворного музиканта (Д. Бортнянський), або безпосередньо були пов'язані з архетиповими настановами української культури та творчістю Т. Шевченка (М. Лисенко, Г. Топольницький, Й. Кишакевич), що становили поетичну основу більшості з названих хорових опусів.

Кантата К. Стеценка «Шевченкові», що створювалася в 1910-1911 pр. безпосередньо до святкових шанувань поета, продовжує цю славослівну «лінію» розвитку жанру, що набула класичних рис у творчості М. Лисенка як фундатора української музики. Будучи послідовником великого класика української музики, К. Стеценко все ж віддавав перевагу хоровим та вокально-інструментальним жанрам, що представлені кантатами («Еднаймося», «У неділеньку, у святую», «Шевченкові», «Слава Лисенкові»), а також численними хорами із супроводом. Окрема і менш досліджена сфера творчості К. Стеценка репрезентована його духовною хоровою спадщиною, основу якої становлять три літургії св. Іоана Золотоустого, Всенічна, Панахида, Вінчання, Пасхальна рання, фрагменти із заупокійної служби, із чину Вінчання, задостойники, канти 
і псальми, колядки і щедрівки, окремі духовні твори тощо. Відзначимо також, що ритуально-богослужбова «лінія» хорового спадку композитора безпосередньо пов'язана з ідеологією Української автокефальної церкви, активний розквіт якої $\epsilon$ співвідносним саме $з$ періодом українського національного духовного відродження початку ХХ ст., до якого К. Стеценко як видатний музичний митець мав безпосередній стосунок.

Аналогічного роду переваги, показові також і для творчості його сучасників - М. Леонтовича, О. Кошиця, Я. Степового й інших, свідчать про свідоме сприйняття сфери хорової музики, хорового співу та їх сакральної генези як домінантної в українській музично-історичній традиції. На думку Н. Синкевич, «<...> природно національна «почуттєва спільнота» - хор - здавна цементується й надихається релігійними переживаннями. Сакральний компонент, що лежить в основі церковно-ритуальної функції хорового співу, влився разом 3 обрядовим і соціопсихологічним в архетипову надфункцію українського хорового мистецтва». Цитований автор уточнює сутність даного феномену та далі вказує: «Останню називаємо надфункцією з огляду на те, що іiї складають традиційно-обрядова, церковно-ритуальна та етноконсолідаційна функції. А виражається архетипова надфункція у здатності пробуджувати у виконавців і слухачів хорового співу «дрімаюче» відчуття причетності до етнічних пракоренів». Таким чином «відбувається містичне злиття з витоками духовного досвіду, 3 «увічненим минулим» (Мігель де Унамуно) шляхом підсвідомого занурення в етноісторію, через віртуальне перебування в колективній душі нації» [17, с. 19].

Позначене світовідчуття й осмислення духовної сутності власної національної культури та її сакральної генези є показовими для багатьох українських митців періоду XIX - початку XX ст., відзначеного «пасіонарним вибухом українства у сфері духовності» [8, с. 6]. Його риси наявні в діяльності українських художників перших десятиріч XX ст., що зверталися до модерної «українізованої візантики» [7, с. 67] (М. Бойчук, М. Сосенко, Ю. Буцманюк, І. Їжакевич, О. Мурашко, П. Холодний, О. Новаківський та інші) та неорелігійних шукань, що проявилися в «розмаїтті художніх засобів при втіленні провідних транскультурних образів-міфологем (М. Вороний, М. Семенко)» [11, с. 11], а також архетипових настанов власне української культури та ії славетних репрезентантів. 
Серед останніх суттєве місце посідає Т. Шевченко, фігура якого в духовно-мистецькому житті України була значущою не тільки як класика національної літератури та поезії, але і як пророка, якому вдалося узагальнити в художньо-поетичній формі практично всі сторони духовного буття свого народу. Абрам Терц свого часу присвятив великому Кобзареві такі слова: «Я не знаю іншого поета, кому б так поклонялися у масі, немов святому, обливаючись сльозами як у церкві, зашкарублі мужики, перед іконою-портретом, у рушниках, на потайному ювілеї, у каптьорці, хором, як Отче наш: - Батьку! Tapace! <...>» [цит. за: 14, с. 250].

Таке практично культове шанування особистості та творчого спадку T. Шевченка є показовим і на початку XX ст., про що, наприклад, свідчить діяльність К. Малицької, чий вірш став текстовою основою кантати К. Стеценка «Шевченкові». Слідом за I. Франком ця поетеса, педагог та видатний громадський діяч усіляко сприяла поширенню в різних регіонах України (і не тільки) культу Кобзаря [див. про це докладніше: 4], прищеплюючи інтерес до його спадщини ще у школярів молодшого віку. Сказане зумовлює специфіку поетичної мови К. Малицької, що відрізняється граничною простотою та ясністю, оскільки здебільшого орієнтована на дитяче сприйняття.

Позначені якості показові й для віршованого тексту кантати К. Стеценка «Шевченкові», що виявляє ознаки славільного жанру. Відсутність сюжетного оповідання тут компенсується констатуванням високої ролі та значущості для України творчості великого Кобзаря:

«Сонцем нам твоя пісня палала, серце живила, душу зміцняла,

Й досі сонце променем сяє, народ твій голос любить і знає.

Бо ти, Кобзарю, вірний народу, ти провіщав нам щастя й свободу,

Завжди братів ти кликав до бою, завжди боровся з кривдою злою <...>».

Значна частина тексту - повторення славослів'я «Честь тобі, слава, батьку Кобзарю!», які в кінцевому підсумку, подібно до завершень відомих українських дум («славнів»), вінчають весь твір. Показово, що за всієї простоти викладення поетичної думки автор апелює до архетипових міфопоетичних образів-настанов українського світовідчуття, акцентує увагу 
на багатоаспектній символіці «сонця», що єднає язичницький та християнській світи; «серця», у якому зосереджено кордоцентризм українського духовного світосприйняття; «кривди», що в усіх фольклорно-міфологічних та історичних оповіданнях стає зосередженням світового зла, з яким треба боротися. Характерною $є$ також родинно-християнська лексика поетеси, у межах якої народ мислиться як спільнота «братів», тоді як сам Кобзар із його духовним досвідом, що «душу зміцняє», є Батьком. Нарешті, показовим у межах українського «образу світу» є сприйняття поезії Т. Шевченка на рівні «пісні» як утілення сакральної сутності українства.

Кантата К. Стеценка «Шевченкові» являє собою одночастинну хорову композицію поемного типу, у якій виділено два підрозділи. Перший із них орієнтований на домінування тональної сфери e-moll, тоді як другий (Andante moderato) представлений як фугато, демонструє послідовний рух до ствердження G-dur, у якому остаточно головує образ хвали-славослів'я великому Кобзарю. Початкова тема першого розділу кантати (Andante sostenuto) побудована на тризвуковому мелодійному русі, що є показовим елементом багатьох жанрів української фольклорної традиції. Ї̈і інтонаційна мова також має перетин з епіко-гімнічним зачином відомої пісні «Реве та стогне Дніпр широкий», виявляє тим самим національні семантичні аспекти «палаючої пісні» Кобзаря. Показовим також є іiі фактурне викладення, що тяжіє до монодії.

Цей музичний матеріал першого розділу доповнюється іншим тематизмом кантати (Allegro maestoso), що експонує iii славословну складову частину (середній розділ), орієнтовану на семантику G-dur. Урочистий хорально-акордовий тип фактури хорової партії доповнений в оркестровій партії юбіляційними фігурами кола-оспівування, типовими для глоріозної поетики та іiі музично-риторичного відтворення. Окрім цього, композитор у даному розділі апелює до виразних терцієвих дублювань мелодичного матеріалу. Кульмінаційні зони («Честь тобі, слава, батько Кобзарю») підкреслені акордовими скандуваннями в хоровій партії, яскравою динамікою, характерними тембровими чергуваннями жіночих та чоловічих голосів, показовими для кола виразних музичних засобів зазначеної вище «алілуйної парадигматики». Скорочена реприза (Andante sostenuto) стає своєрідним підсумком позначених образно-виразних інтонаційних сфер першого 
розділу кантати, підкреслених також контрастним зіставленням баса, що солює, та потужного хорового tutti, що виявляють барокову природу цього прийому.

Другий розділ кантати (Andante moderato) апелює до фугато, що демонструє поліфонічну майстерність музичного стилю К. Стеценка. Співучий характер теми (e-moll) у поєднанні 3 імітаційними формами викладення в поступовому русі від басів до сопрано виявляє оригінальність єднання у творі слов'янської пісенності із західноєвропейським музично-теоретичним надбанням.

Цікавим видається також апелювання композитора в заключній частині свого твору до поліфонічних форм, що становить також одну з показових ознак буття розділу Gloria в духовних музичних композиціях авторів Нового часу аж до XX ст. На думку А. Татарнікової, такий інтерес до поліфонії зумовлений «не тільки структурно-композиційними і фактурними особливостями фуги, але й іiі концептуально-семантичними аспектами, що представляють даний жанр як «як певний спосіб художнього моделювання світу», а також як утілення «ідеї єдності і гармонії світобудови як концептуальної домінанти» [18, с. 167]. Відзначимо, що звернення К. Стеценка до цього прийому виявляє, з одного боку, його причетність до жанрово-інтонаційного виразного ареалу європейської музичної культури та її творчого надбання. 3 іншого боку, його репрезентація в аналізованій кантаті виявляє національний авторський підхід композитора, оскільки, як вказувалося раніше, текстово-семантичне навантаження фінальної частини твору, що акщентує образи «пам'яті», «слави», «честі», співвідносних з ім'ям Кобзаря, має очевидні аналогії зі «славнями» українських дум та їхньою інтонаційною специфікою.

Висновки. Отже, хорова кантата є одним із показових жанрів української музично-історичної традиції протягом декількох останніх століть. Поетика цього жанру виступає своєрідною єднальною ланкою між літургічною та паралітургічною сферами творчості. Особливе акцентування славослівної складової частини в кантаті зумовлене етимологією іiі кореневої основи ("сапо" - «співати», «оспівувати», «прославляти»), грунтується на давніх традиціях української та загалом слов'янської культури. Хорова кантата являє собою один із показових жанрових зразків утілення «алілуйної парадигматики європейської культури та музики» (А. Татарнікова), що 
тяжіє до уславлення значних постатей українського духовно-історичного буття, які єднають спільноту та репрезентують iii національну ідею. Одне із провідних місць у цьому переліку належить Тарасу Шевченко, чий поетичний спадок узагальнює найбільш показові якості українського духовного світовідчуття, що набували особливої актуальності в період національного відродження межі XIX-XX ст. Поетика хорової кантати К. Стеценка «Шевченкові» (на тексти К. Малицької) апелює, з одного боку, до типологічних ознак славослівної кантати та їі музично-риторичної символіки (юбіляції, барокові протиставлення solo та tutti, звертання до поліфонічних форм викладення у фінальній частині твору як ознаки глоріозного жанру). 3 іншого боку, епіко-славільний тонус твору К. Стеценка, особливо його заключного розділу, виявляє співвіднесеність із композиційними настановами українських дум, зокрема з їхніми фінальними «славнями».

\section{СПИСОК ЛІТЕРАТУРИ}

1. Агапкина Т. Слава в восточнославянском фольклоре. Kaтегория оценки и система ценностей в языке и культуре / отв. ред. С. Толстая. Москва : Индрик, 2015. С. 109-166.

2. Асоян Ю., Малафеев А. Открытие идеи культуры : Опыт русской культурологии середины XIX - начала XX в. Москва : ОГИ, 2000. $344 \mathrm{c}$.

3. Гайдучик Д. Синтез народнопісенних та церковно-монодичних витоків у духовних циклах Кирила Стеценка. Українське музикознавство. 2013. Вип. 39. С. 164-193.

4. Гірняк С. Образ Тараса Шевченка в житті та творчості Костантини Малицької. Рідне слово в етнокультурному вимірі / гол. ред. М. Федурко. Дрогобич : Дрогобицький державний педагогічний університет ім. І. Франка, 2019. С. 110-121.

5. Дзюба I. Тарас Шевченко. Життя і творчість. Київ : Видавничий дім «Києво-Могилянська академія», 2008. 718 с.

6. Історія українського мистецтва: у 5-ти т. / гол. ред. Г. Скрипник. Київ : НАН України, ІМФЕ ім. М.Т. Рильського, 2011. Т. 3 : Мистецтво другої половини XVI-XVIII ст. 1088 с.

7. Історія українського мистецтва : у 5-ти т. / гол. ред. Г. Скрипник. Київ : НАН України, ІМФЕ ім. М.Т. Рильського, 2007. Т. 5 : Мистецтво XX ст. 1048 с.

8. Історія української музики : у 6-ти т. / редкол. : Г. Скрипник (гол.) та ін. Київ : НАН України, ІМФЕ ім. М.Т. Рильського, 2009. T. 2 : XIX ст. 800 c.

9. Исупов К. Павел Флоренский: наследие и наследники. П.А. Флоренский: pro et contra. Санкт-Петербург : РХГИ, 1996. С. 7-9. 
10. Cano. URL: https://ru.wiktionary.org/wiki/cano_Латинский (дата звернення: 12.06.2020).

11. Каранда М. Неорелігійні мотиви в естетиці та мистецтві зламу ХІХ-XX ст. : автореф. дис. ... канд. філос. наук: 09.00.08. Київ, 2006. 18 с.

12. Кирило Стеценко : Спогади. Листи. Матеріали / упор. і вст. стаття Є. Федотова. Київ : Музична Україна, 1981. 410 с.

13. Кононенко В. Концепти українського дискурсу : монографія. Київ ; Івано-Франківськ : Плай, 2004. 248 с.

14. Муравська О. Східнохристиянська парадигма європейської культури і музика XVIII-XX ст. : монографія. Одеса : Астропринт, 2017. $564 \mathrm{c}$.

15. Пархоменко Л. Кирило Стеценко. Київ : Мистецтво, 1963. $232 \mathrm{c}$.

16. Плотникова А. Слава. Этнолингвистический словарь славянских древностей. Проект словника. Предварительные материалы. Москва : Институт славяноведения и балканистики, 1984. С. 161-170.

17. Синкевич Н. Сакральний компонент архетиповості українського хорового мистецтва. Вісник Львівського університету. Серія «Мистецтвознавство». 2013. Вип. 13. С. 16-23.

18. Татарнікова А. Алілуйна парадигма європейської культури i музики (від готики до сучасності) : монографія. Одеса : Астропринт, 2020. 344 c.

19. Терещенко А. Українська радянська кантата і ораторія (1945-1974). Київ : Наукова думка, 1975. 176 с.

20. Ясиновський Ю. Візантійська гимнографія і церковна монодія в українській монодії ранньомодерного часу : монографічне дослідження. Львів : Інститут українознавства ім. І. Крип'якевича НАН України, 2011. 468 с.

\section{REFERENCES}

1. Agapkina, T. (2015). Glory in East Slavic folklore. Kategoriya otsenki i sistema tsennostey v yazyke i kul'ture. Moscow: Indrik, pp. 109-166 [in Russian].

2. Asoyan, Yu., Malafeyev, A. (2000). Discovery of the Idea of Culture: The Experience of Russian Cultural Studies of the Mid 19'th Early 20'th Centuries. Moscow: OGI [in Russian].

3. Hayduchik, D. (2013). Synthesis of folk-verse and churchmonodic origins in the spiritual cycles of Cyril Stetsenko. Ukrayins'ke muzykoznavstvo, 39, pp. 164-193 [in Ukrainian].

4. Hirnyak, S. (2019). The image of Taras Shevchenko in the life and work of Konstantina Malytska. Ridne slovo v etnokul'turnomu vymiri. Drohobych: Drohobychs'kyy derzhavnyy pedahohichnyy universytet im. I. Franka, pp. 110-121 [in Ukrainian].

5. Dzyuba, I. (2008). Taras Shevchenko. Life and work. Kiev: Vydavnychyy dim "Kyyevo-Mohylyans'ka akademiya" [in Ukrainian]. 
6. History of Ukrainian art: in 5 vols (2011). Kiev: NAN Ukrayiny, IMFE im. M.T. Ryl's'koho. Vol. 3 [in Ukrainian].

7. History of Ukrainian art: in 5 vols (2007). Kiev: NAN Ukrayiny, IMFE im. M.T. Ryl's'koho. Vol. 5 [in Ukrainian].

8. History of Ukrainian music: in 6 volumes (2009). Kiev : NAN Ukrayiny, IMFE im. M.T. Ryl's'koho. Vol. 2 [in Ukrainian].

9. Isupov, K. G. (1996). Pavel Florensky: heritage and heirs. P.A. Florenskiy: pro et contra. St. Petersburg: RHGİ [in Russian].

10. Cano (2020). Retrieved from https://ru.wiktionary.org/wiki/cano_.

11. Karanda, M.V. (2006). Neo-religious motives in the aesthetics and art of the turn of the XIX-XX centuries. Extended abstract of candidate's thesis. Kiev: Kyyivs'kyy natsional'nyy universytet imeni Tarasa Shevchenka [in Ukrainian].

12. Kyrylo Stetsenko (1981). Memoirs. Letters. Materials. Kiev: Muzychna Ukrayina [in Ukrainian].

13. Kononenko, V. (2004). Concepts of Ukrainian discourse: Monograph. Kyiv - Ivano-Frankivsk: Play [in Ukrainian].

14. Muravs'ka, O.V. (2017). Eastern christian paradigm of european culture and music of the XVIII-XX centuries. Odessa: Astroprint [in Ukrainian].

15. Parkhomenko, L. (1963). Kirilo Stetsenko. Kiev: Mystetstvo [in Ukrainian].

16. Plotnikova, A. (1984). Glory. Etnolingvisticheskiy slovar'slavyanskikh drevnostey. Proyekt slovnika. Predvaritel'nyye materialy. Moscow: Institut slavyanovedeniya i balkanistiki, pp. 161-170 [in Russian].

17. Sinkevich, N. (2013). The sacred component of the archetype of Ukrainian choral art. Visnyk L'vivs'koho universytetu. Seriya: Mystetstvoznavstvo, 13, pp. 16-23 [in Ukrainian].

18. Tatarnikova A.A. (2020). Hallelujah paradigm of European culture and music (from Gothic to the present): monograph. Odessa: Astroprint [in Ukrainian].

19. Tereshchenko, A.K. (1975). Ukrainian Soviet cantata and oratorio (1945-1974). Kiev: Naukova dumka [in Ukrainian].

20. Yasynovs'kyy, Yu. (2011). Byzantine hymnography and church monody in the Ukrainian monody of early modern times: A monographic study. Lviv: Instytut ukrayinoznavstva im. I. Kryp'yakevycha NAN Ukrayiny [in Ukrainian]. 